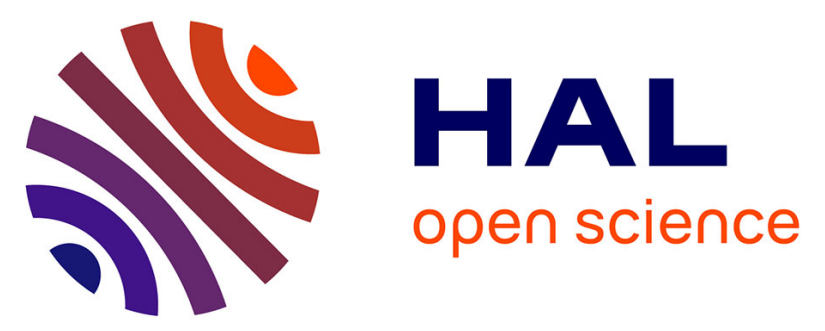

\title{
Methanogenic potential of forages consumed throughout the year by cattle in a Sahelian pastoral area
}

Michel Doreau, Hanen Benhissi, Yakhya Elhadji Thior, Bérénice Bois, Claire

Leydet, Lucette Genestoux, Philippe Lecomte, Diego Morgavi, Alexandre

Ickowicz

\section{To cite this version:}

Michel Doreau, Hanen Benhissi, Yakhya Elhadji Thior, Bérénice Bois, Claire Leydet, et al.. Methanogenic potential of forages consumed throughout the year by cattle in a Sahelian pastoral area. Animal Production Science, 2016, 56 (2-3), pp.613-618. 10.1071/AN15487 . hal-01281831

\section{HAL Id: hal-01281831 \\ https://hal.science/hal-01281831}

Submitted on 2 Mar 2016

HAL is a multi-disciplinary open access archive for the deposit and dissemination of scientific research documents, whether they are published or not. The documents may come from teaching and research institutions in France or abroad, or from public or private research centers.
L'archive ouverte pluridisciplinaire HAL, est destinée au dépôt et à la diffusion de documents scientifiques de niveau recherche, publiés ou non, émanant des établissements d'enseignement et de recherche français ou étrangers, des laboratoires publics ou privés. 


\title{
Methanogenic potential of forages consumed throughout the year by cattle in a Sahelian pastoral area
}

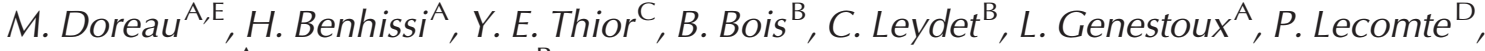 \\ D. P. Morgavi ${ }^{\mathrm{A}}$ and A. Ickowicz ${ }^{\mathrm{B}}$ \\ AINRA, UMR Herbivores, 63122 Saint-Genès Champanelle, France. \\ ${ }^{B}$ CIRAD, UMR Selmet, Campus de Baillarguet, 34398 Montpellier Cedex 5, France. \\ CISRA, LNERV, PPZS, BP 2057, Dakar, Senegal. \\ ${ }^{D}$ CIRAD, UMR Selmet, PPZS, 37 Avenue Jean XXIII, Dakar, Senegal. \\ ${ }^{\mathrm{E} C o r r e s p o n d i n g}$ author. Email: michel.doreau@Clermont.inra.fr
}

\begin{abstract}
Methane $\left(\mathrm{CH}_{4}\right)$ emission from ruminants in African pastoral systems may be affected by intake and type of plants, which vary highly between rainy and dry seasons. In each of two sites located in the semiarid Sahelian area of Senegal, three Gobra zebus were monitored throughout 1 year. A representative sample of their diet was obtained once every month. Diet was mainly composed of grasses, herbaceous legumes, tree and shrub foliage and pods, and dried forage residues. $\mathrm{CH}_{4}$ production and volatile fatty acid (VFA) concentration, which reflects VFA production, were determined in vitro. Crude protein, neutral detergent fibre (NDF) and acid detergent fibre were measured by near-infrared spectrophotometry. $\mathrm{CH}_{4}$ production varied between 24.6 and $35.2 \mathrm{~mL} / \mathrm{g}$ forage dry matter (DM), being minimal in August (rainy season) and maximal in February (dry season). Seasonal difference disappeared when $\mathrm{CH}_{4}$ was expressed in $\mathrm{mL} / \mathrm{g}$ NDF. The acetate : propionate ratio varied in the same way as $\mathrm{CH}_{4}$ (3.2 and 4.6 in August and February, respectively); VFA concentration was minimum in March and maximum in September (69.2 and $77.4 \mathrm{mmol} / \mathrm{L}$, respectively). $\mathrm{CH}_{4}$ production was closely related to dietary NDF content $(r=0.82)$ and to acetate : propionate ratio $(r=0.96)$. For six successive periods (February to July), plant categories constituting the diet were incubated separately. Reconstituting the $\mathrm{CH}_{4}$ production and VFA concentration in the diet on the basis of the proportion of plant components gave values similar to those of the global diet $\left(33.4\right.$ and $34.2 \mathrm{~mL} \mathrm{CH}_{4} / \mathrm{g} \mathrm{DM}$ and 75.9 and $70.9 \mathrm{mmol} \mathrm{VFA} / \mathrm{L}$, respectively). This result suggests the absence of interaction among plant components on rumen fermentation.
\end{abstract}

Additional keywords: greenhouse gases, rumen, seasonal variations.

Received 27 August 2015, accepted 28 October 2015, published online 9 February 2016

\section{Introduction}

The contribution of livestock to total greenhouse gas (GHG) emissions is evaluated as $14.5 \%$ of emissions of anthropogenic origin, of which $39 \%$ is represented by enteric methane $\left(\mathrm{CH}_{4}\right)$ emissions (Gerber et al. 2013). Although regions having a low animal productivity contribute to a low extent to GHG emissions (e.g. $10 \%$ for subsaharan Africa), enteric $\mathrm{CH}_{4}$ emissions per kilogram of milk or meat are the highest when productivity is very low (Gerber et al. 2011). However, there are very few direct measurements of $\mathrm{CH}_{4}$ emissions in tropical countries, and, to our knowledge, there is none for pastoral systems, so that it is necessary to better evaluate emissions and understand factors responsible for emission variation, before proposing ways of mitigation. In pastoral areas, major factors of variation of $\mathrm{CH}_{4}$ emissions are the level of intake of forages as well as their nature and nutritive value, which vary greatly throughout the year, for grass as for browse species (Ouédraogo-Koné et al. 2008). This is especially marked in Sahelian climatic conditions that have high seasonal and inter-annual rainfall variability (Lebel et al. 2003). Despite the benefits of partial transhumance for cattle nutrition (Gaidet and Lecomte 2013), annual changes in intake and forage quality remain high (Chirat et al. 2014). On-field in vivo measurements of enteric $\mathrm{CH}_{4}$ emissions are very difficult to implement for methodological reasons. To overcome this difficulty, in vitro tests are proposed as a first evaluation method. A preliminary study on Sahelian forages harvested in a pastoral area of Senegal showed the impact of forage chemical composition on $\mathrm{CH}_{4}$ production in vitro (Baccouche et al. 2014). The main objective of the present study was to evaluate the potential of $\mathrm{CH}_{4}$ emissions from forage diets consumed by cattle across different seasons, and to relate $\mathrm{CH}_{4}$ production with forage chemical composition. A secondary objective was to assess potential interactions between forage components, i.e. changes in $\mathrm{CH}_{4}$ emission when the different dietary forage components are fermented alone or mixed together, as they are in diets.

\section{Materials and methods}

Experimental sites and design

The study took place in two experimental sites in northern Senegal, in the Ferlo silvopastoral area. This is a semiarid 
region, with a Sahelian climate (Bwh in the Köppen classification), with annual average temperature and rainfall of $28-30^{\circ} \mathrm{C}$ and $200-400 \mathrm{~mm}$, respectively (Touré et al. 2012). Rainy season generally occurs between July and September; dry season is longer, occurring between October and June. Due to this climatic context, Ferlo area is devoted to transhumant systems for free-ranging cattle; herds move from north in rainy season to south in dry season. The first experimental site $\left(15^{\circ} 21^{\prime} \mathrm{N}, 15^{\circ} 28^{\prime} \mathrm{W}\right)$ was the research station of Dahra-Djoloff (ISRA Animal Research Centre, BP 01, Dahra, Senegal). Three Gobra young bulls (aged 2.5 years and weighing on average $230 \mathrm{~kg}$ ) among a sedentary herd of 120 cattle were monitored between early February and late September 2014. The second experimental site was a larger area around the village of Niassanté $\left(16^{\circ} 10^{\prime} \mathrm{N}, 15^{\circ} 33^{\prime} \mathrm{W}\right)$. Three Gobra cows (aged 7.5 years and weighing on average $260 \mathrm{~kg}$ ) among a herd of 31 transhumant adult cattle belonging to a Fulani breeder were monitored during the same period. Transhumant system in this area has been described by Adriansen and Nielsen (2005). Sites are called S (sedentary) and N (nomadic), respectively. In both sites, nine 3-day periods of measurement were defined, with an interval of 1 month between the measurement periods. Rainfall during these periods was in compliance with the abovementioned general trend.

Animals were free-ranging and were fed almost exclusively on rangelands composed of grasses, of which the major species were Aristida mutabilis, Chloris prieurii, Dactyloctenium aegyptium, Eragrotris tremula and Schoenefeldia gracilis, of herbaceous legumes, of which the major species were Alysicarpus ovalifolius, Cassia obtusifolia and Zornia glochidiata, and of shrubs, especially Balanites aegyptiaca, Boscia senegalensis and Calotropis procera. Other herbaceous plants, such as Achyranthes aspera, Borrelia sp. and Sporobolus coromandelianus, were also found.

\section{Measurements and analyses}

Forage samples were obtained by the simulated-bite technique that mimics forage intake by animals, described by Guérin et al. (1988) and validated by Wallis de Vries (1995). Hand-plucking was performed for 1 day for each cattle between sunrise and sunset, so as to obtain a representative sample of consumed forage for each animal. Sampling was performed on each site and for all periods by the same person for the three cattle on three successive days. Daily samples were collected in a 50-L bag, and then air-dried. From this representative sample, forage diet was sorted into the following categories: grasses, herbaceous legumes, perennial herbs other than grasses and legumes, foliage and pods of ligneous shrubs and trees, and a category called 'straw'. This last category contained diverse undefined forage made of residual grass stems. After sorting, samples of each category were oven-dried at $60^{\circ} \mathrm{C}$ for $48 \mathrm{~h}$ to determine the percentage of each plant category on a dry matter (DM) basis.

In vitro fermentation of forage samples was performed using a batch system, as described in Rira et al. (2015). For each period and each animal, a subsample of the global diet was assayed $(n=54)$, and for six periods from February to July for the same animal in Niassanté site, the corresponding subsamples by category (grasses, herbaceous legumes, shrubs and trees, 'straw', $n=24$ ) were also assayed. Each forage sample was assayed in two runs. Successive runs were separated by 3 days. Donor animals were three wethers of Texel breed, weighing on average $70 \mathrm{~kg}$, and receiving daily $1000 \mathrm{~g}$ of chopped natural grassland hay from tropical origin. For each run, a 500-g sample of rumen content was obtained from each animal, then strained through a $250-\mu \mathrm{m}$ mesh polyester cloth. Filtrates of the three wethers were pooled for constituting the fermentation inoculum. Incubations lasted $24 \mathrm{~h}$, with $400 \mathrm{mg}$ of forage, $15 \mathrm{~mL}$ inoculum and $25 \mathrm{~mL}$ buffer placed in $100-\mathrm{mL}$ vials. Gas production was measured using a pressure transducer. Conditions of fermentation, and gas and liquid sampling procedures are described in Rira et al. (2015). $\mathrm{CH}_{4}$ was determined in a gas sample by gas chromatography (Micro GC 3000A, Agilent Technologies, Les Ulis, France). Volatile fatty acids (VFA) were determined by gas chromatography using crotonic acid as an internal standard (Perkin-Elmer Clarus 580 GC, Perkin Elmer, Courtaboeuf, France), as described by Morgavi et al. (2013).

All forage samples were analysed for neutral detergent fibre (NDF), acid detergent fibre (ADF) and crude protein (CP) by near-infrared reflectance spectroscopy (NIRS) using a Foss NIRsystem 5000 monochromator (Foss, Hillerod, Denmark), according to equations determined from the comparison of spectra of more than 1300 tropical forages with chemical analyses (Tran et al. 2010).

The first set of data was formed with all results of fermentation and chemical composition of representative forage diets for the six animals and nine periods. ANOVAs were performed using the mixed procedure of SAS (v9.3; SAS Institute Inc., Cary, NC, USA). The first analysis was performed with the model $Y=\mu+$

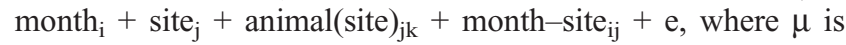
the overall mean, month is treated as a repeated factor, animal is nested within site, month-site is the interaction between month and site and e is the error. The second analysis was performed with the model $Y=\mu+$ season $_{\mathrm{i}}+$ site $_{\mathrm{j}}+$ animal $(\text { site })_{\mathrm{jk}}+$ season-site $_{\mathrm{ij}}+\mathrm{e}$, where the season factor has two levels, namely, dry or rainy. Linear correlations were then established among all selected variables. The second set of data was formed by six representative diets for successive months on one hand, and the six corresponding reconstituted diets, $\mathrm{R}$, on the other, obtained as follows: $\mathrm{R}=\Sigma \mathrm{C}_{\mathrm{i}} \times P_{\mathrm{i}}$, where $\mathrm{C}_{\mathrm{i}}$ is the value of each variable for forage category $i(i=$ grasses, herbaceous legumes, trees and shrubs, 'straw') and $P_{\mathrm{i}}$ the proportion of each category on a DM basis in the original forage diet. An ANOVA was performed using the model $Y=$ $\mu+\operatorname{method}_{\mathrm{i}}+\operatorname{month}_{\mathrm{j}}+\mathrm{e}$, where $\mu$ is the overall mean, method is the mode of calculation (initial vs reconstituted sample), month is the month of harvesting and e is the error. For all analyses, significance was declared at $P<0.05$.

\section{Results}

\section{Variation in fermentation according to the season}

There was large variation in the chemical composition of forage diets according to the month of harvesting, cell walls being the highest and $\mathrm{CP}$ being the lowest in dry season (Table 1). $\mathrm{CH}_{4}$ production expressed in $\mathrm{mL} / \mathrm{g}$ DM was the highest in February, April and May (32-35 mL/g DM), when NDF content was the 
highest, and was the lowest between August and September (24-25 $\mathrm{mL} / \mathrm{g} \mathrm{DM}$ ), when NDF content was the lowest $(P<0.001) . \mathrm{CH}_{4}$ production expressed in $\mathrm{mL} / \mathrm{g}$ NDF also varied according to the month $(P<0.001)$, but changes from one harvesting date to the subsequent one could be important; for example, the lowest and the highest production were in early August and late August, respectively. Differences in the VFA concentration were significant but less marked $(P=0.034)$, being lower between February and April (69-71 mmol/L) than between May and September (74-76 mmol/L). VFA pattern also varied, depending on the month of harvest $(P<0.001)$. Acetate was lower between July and September (67-69\%) than between February and June (70-73\%), propionate was higher between July and September (20-21\%) than between February and June (16-19\%); as a consequence, the acetate: propionate ratio was higher between February and June (3.79-4.62) than between July and September (3.16-3.61). Butyrate did not change with the month of harvesting ( $P=0.08$, data not shown). Comparison between rainy and dry seasons (Table 2) confirmed most of these results, i.e. a huge difference in CP content (5.4 vs $17.5 \mathrm{~g} / \mathrm{kg}$ DM for dry and rainy seasons, respectively), significantly higher cell wall content in dry season, significantly lower $\mathrm{CH}_{4}$ production per g DM (31.5 vs $24.3 \mathrm{~mL} / \mathrm{g}$ DM for dry and rainy seasons, respectively), significantly lower acetate proportion, acetate: propionate ratio, and significantly higher VFA concentration and propionate proportion in rainy season than in dry season; however, $\mathrm{CH}_{4}$ production per gram NDF did not vary with season.

Differences in chemical composition were observed between the two sites, forage diets being higher in NDF and lower in CP at Site N than at Site S (63.5 vs 59.6 g/kg DM, respectively), whereas $\mathrm{CP}$ and ADF concentrations were not significantly different between the sites. $\mathrm{CH}_{4}$ production per gram DM was higher for Site $\mathrm{N}$ than for Site S (29.8 vs $26.1 \mathrm{~g} / \mathrm{kg}$ DM, respectively), but $\mathrm{CH}_{4}$ production per gram NDF remained unchanged. VFA concentration did not change with site; acetate proportion and acetate : propionate ratio were higher, and propionate proportion was lower at Site $\mathrm{N}$ than at Site $\mathrm{S}(70.5,18.5$ and 3.94 for Site N, 68.9, 20.4 and 3.44 for Site $\mathrm{S}$, respectively). Differences in $\mathrm{CH}_{4}$ production per gram DM between the sites were more marked in

Table 2. Seasonal variation of chemical composition and in vitro fermentation characteristics of forage diets consumed by cattle in Sahelian pastures

$\mathrm{ADF}$, acid detergent fibre; $\mathrm{CP}$, crude protein; DM, dry matter; NDF, neutral detergent fibre; VFA, volatile fatty acids. Se, season; $\mathrm{Si}$, site; $\mathrm{Se} \times \mathrm{Si}$, season $\times$ site interaction

\begin{tabular}{lcccccc}
\hline Parameter & \multicolumn{2}{c}{ Season } & s.e.m. & \multicolumn{3}{c}{$P$-value } \\
& Dry & Rainy & & Se & \multicolumn{1}{c}{$\mathrm{Si}$} & $\mathrm{Se} \times \mathrm{Si}$ \\
\hline $\mathrm{CP}(\mathrm{g} / \mathrm{kg} \mathrm{DM})$ & 5.43 & 17.53 & 1.192 & $<0.001$ & 0.352 & 0.461 \\
NDF $(\mathrm{g} / \mathrm{kg} \mathrm{DM})$ & 68.8 & 54.3 & 1.46 & $<0.001$ & 0.012 & 0.953 \\
ADF $(\mathrm{g} / \mathrm{kg} \mathrm{DM})$ & 43.1 & 30.6 & 0.93 & $<0.001$ & 0.687 & 0.230 \\
Methane $(\mathrm{mL} / \mathrm{g}$ DM) & 31.5 & 24.3 & 0.91 & $<0.001$ & 0.001 & 0.020 \\
Methane (mL/g NDF) & 45.6 & 45.4 & 1.43 & 0.876 & 0.069 & 0.025 \\
VFA (mmol/L) & 72.3 & 75.8 & 1.55 & 0.008 & 0.146 & 0.380 \\
Acetate $(\% \mathrm{VFA})$ & 71.7 & 67.7 & 0.58 & $<0.001$ & 0.008 & 0.466 \\
Propionate $(\%$ VFA $)$ & 21.4 & 17.5 & 0.45 & $<0.001$ & $<0.001$ & 0.239 \\
Acetate : propionate & 4.19 & 3.19 & 0.121 & $<0.001$ & $<0.001$ & 0.071 \\
\hline
\end{tabular}


dry season than in rainy season (significant interaction between season and site).

When considering the nine periods and the six animals $(n=54), \mathrm{CH}_{4}$ production per gram DM was significantly $(P<0.001)$ correlated with $\mathrm{CP}, \mathrm{NDF}$ and ADF concentrations ( $r=-0.60,0.82$ and 0.74 , respectively), with VFA concentration, with acetate, propionate and butyrate proportions, and with acetate : propionate ratio $(r=-0.55,0.85,-0.96,0.47$ and 0.96 , respectively). $\mathrm{CH}_{4}$ production per gram NDF was not correlated with $\mathrm{CP}$ and, obviously, with $\mathrm{NDF}$ and $\mathrm{ADF}$ contents, but was correlated with $\mathrm{CH}_{4}$ per g DM, propionate proportion and acetate: propionate ratio $(r=0.52,-0.45$ and -0.53 , respectively, $P<0.001)$, with acetate proportion $(r=$ $0.36, P<0.01)$, and with VFA concentration and butyrate proportion $(r=-0.33$ and 0.29 , respectively, $P<0.05)$. VFA concentration was significantly correlated with CP, NDF and ADF concentrations $(r=0.29, P<0.05,-0.40$ and $-0.35, P<0.01$, respectively), with acetate proportion $(r=-0.29, P<0.05)$, with propionate and butyrate proportions and with acetate: propionate ratio $(r=0.51,-0.69$ and $-0.50, P<0.001$, respectively).

\section{Synergy for fermentation between diet components}

The range in the proportion of the different plant categories in forage diets was $8.1-33.8 \%$ for grasses, $1.2-63.1 \%$ for legumes, $1.0-10.3 \%$ for ligneous and $15.0-79.8 \%$ for 'straw', according to the month of harvesting. Dry season was characterised by the increase in intake of ligneous plants and straw. Chemical composition did not vary between the initial diet and reconstituted diet (Table 3), which indicates that sampling for analyses was conducted correctly. $\mathrm{CH}_{4}$ production, VFA concentration and acetate : propionate ratio did not vary between the initial diet and reconstituted diet, whereas proportions of acetate and propionate were or tended to be higher for the reconstituted diet, at the expense of the proportion of butyrate (Table 3 ).

Table 3. Comparison of methane production and volatile fatty acid (VFA) concentration in vitro between a grazed Sahelian diet fermented as a whole, and the reconstitution from diet components fermented separately

The four diet components were grasses, herbaceous legumes, trees and shrubs, and 'straw' containing undefined forage made of residual grass stems. ADF, acid detergent fibre; $\mathrm{CP}$, crude protein; DM, dry matter; NDF, neutral detergent fibre

\begin{tabular}{lccll}
\hline Item & $\begin{array}{c}\text { Diet } \\
\text { fermentation }\end{array}$ & $\begin{array}{c}\text { Reconstitution from } \\
\text { diet-component } \\
\text { fermentation }\end{array}$ & s.e.m. & $P$-value \\
\hline CP (\% DM) & 5.57 & 5.30 & 0.387 & 0.44 \\
NDF (\% DM) & 69.7 & 70.9 & 1.53 & 0.38 \\
ADF (\% DM) & 44.0 & 45.3 & 1.34 & 0.27 \\
Methane (mL/g DM) & 34.23 & 33.41 & 1.248 & 0.46 \\
VFA (mmol/L) & 70.86 & 75.95 & 3.591 & 0.14 \\
Acetate (\% VFA) & 73.41 & 74.36 & 0.455 & 0.05 \\
Propionate (\% VFA) & 16.42 & 17.59 & 0.607 & 0.06 \\
Butyrate (\% VFA) & 6.26 & 4.92 & 0.273 & 0.002 \\
Acetate : propionate & 4.52 & 4.30 & 0.186 & 0.21 \\
\hline
\end{tabular}

\section{Discussion}

Changes in methanogenic potential of forage diet with season

Enteric $\mathrm{CH}_{4}$ emissions in tropical countries are not well estimated, especially for low-producing animals, due to insufficient information on feed intake and diet composition. In these countries, enteric $\mathrm{CH}_{4}$ calculation for national $\mathrm{GHG}$ inventories are often performed using the approximate Tier 1 method of IPCC (2006) that does not account for production level of animals. Improvements are in progress; for example, Kouazounde et al. (2015) proposed for enteric $\mathrm{CH}_{4}$ a Tier 2 method adapted for Benin. However, no method can be applied for pastoral systems having a very low animal productivity.

Pastoral systems are characterised by large changes between dry and rainy season, both in feed intake, which can be very low in dry season (Schlecht et al. 1999; Chirat et al. 2014), and in chemical composition, with forages being very low in protein in dry season (Rivière 1991; Schlecht et al. 1999); these two factors concur to changes in $\mathrm{CH}_{4}$ emissions. Our results showed a highly significant effect of season on $\mathrm{CH}_{4}$ production per gram DM, which is higher in dry season than in rainy season. To our knowledge, such result had not been shown previously for tropical pastoral areas. Differences in $\mathrm{CH}_{4}$ production per gram $\mathrm{DM}$ between the two sites could be due to the difference in herd management (nomadic vs sedentary) leading to higher NDF content in the nomadic site, but an effect of local climatic and soil conditions is not excluded. Our results also showed a strong relationship between $\mathrm{CH}_{4}$ production per gram DM and NDF concentration. This result agrees with results of Gemeda and Hassen (2014) who studied 16 grass species in the arid region of Kalahari with comparable climatic conditions, but not with those observed by Baccouche et al. (2014) who performed in vitro incubations of 83 forages, of which 35 were grasses and legumes, harvested in the Ferlo region as in the present study, or those by Macheboeuf et al. (2014) who studied 156 temperate plants, of which only one was grass and 13 were legumes. Our results are especially surprising because $\mathrm{CH}_{4}$ production from forages depend both on their NDF concentration and on their digestibility, which are the two main drivers of hydrogen production from carbohydrate fermentation (Archimède et al. 2011). In the present study, NDF concentration seems to have a much greater effect on $\mathrm{CH}_{4}$ production than does NDF digestibility; this results in the absence of seasonal differences in $\mathrm{CH}_{4}$ production per gram NDF. Possibly, the discrepancy between the present study and that of Gemeda and Hassen (2014), on one hand, and those of Baccouche et al. (2014) and Macheboeuf et al. (2014), on the other hand, could be due to the presence of a majority of grasses ('straw' being mainly composed of grasses) and to the higher NDF concentration in the former two studies. Despite the higher $\mathrm{CH}_{4}$ production per gram DM in the dry season, the very low intake that was simultaneously observed will certainly result in a lower emissions per animal, although $\mathrm{CH}_{4}$ emission rate for a same diet is lower at low intakes (Chaokaur et al. 2015, for Brahman zebus in the tropics).

$\mathrm{CH}_{4}$ emissions per gram DM were closely and positively related to acetate proportion in VFA and acetate : propionate ratio, and negatively related to VFA concentration and propionate proportion in the VFA. These results partially agree with those 
of Gemeda and Hassen (2014) who found a loose but significant positive relationship between $\mathrm{CH}_{4}$ and acetate proportion in the VFA, but no relationship between $\mathrm{CH}_{4}$ production and VFA concentration, propionate proportion in VFA and acetate: propionate ratio. These results are surprising because methanogenesis is thought to be positively related to VFA. This decoupling between the VFA concentration (and thus production) and $\mathrm{CH}_{4}$ production was already observed by Bodas et al. (2008) who incubated 450 temperate plants, of which a small proportion had an antimethanogenic effect, by Meale et al. (2012) for Australian and Ghanean grasses and leguminous shrubs, and by Baccouche et al. (2014) with herbaceous species, but not with ligneous species. Conversely, Macheboeuf et al. (2014) found a good relationship between VFA and $\mathrm{CH}_{4}$ production for 156 temperate species, and a very strong relationship between VFA and total gas production. Collectively, these results suggest that among forages, stoichiometric relationships between VFA and $\mathrm{CH}_{4}$ cannot be used, and that hydrogen produced by carbohydrate fermentation is not totally directed towards $\mathrm{CH}_{4}$ production, at least in vitro.

The present study is a first step in the knowledge of enteric $\mathrm{CH}_{4}$ emissions in Sahelian pastoral areas. In the present study, donor sheep from a temperate breed were fed tropical forage. It is assumed that under these conditions, influence of the donor animal is low, because $\mathrm{CH}_{4}$ emissions depend more on forage (especially temperate vs tropical) than on breed (temperate vs tropical; Archimède et al. 2013). However, a relationship between in vitro and in vivo determination of $\mathrm{CH}_{4}$ emissions per gram DM cannot be established. Indeed (1) batch fermentations are simplified models of the rumen that do not faithfully reproduce in vivo conditions, and (2) all forages were tested with the same inoculum, whereas rumen microbiota certainly varies with the nature of the diet and with undernutrition. The present study showed seasonal variations in $\mathrm{CH}_{4}$ emission, and in vivo on-pasture determination of these emissions is the mandatory next step.

\section{Interaction among diet components}

It has been suggested for a long time that interactions between feedstuffs occur in the rumen, especially due to the need of simultaneous supply of carbohydrates and protein. These interactions, studied first between forages and concentrates, have been assessed more recently among different forages (review by Niderkorn and Baumont 2009). These authors identified digestive interactions when a low-nitrogen forage is associated with a high-nitrogen forage, and when forages rich in secondary metabolites such as tannins are associated with grasses. These two types of association are observed in Sahelian natural grasslands. The former contributes to an increase in VFA concentration, and, thus, in hydrogen, and then $\mathrm{CH}_{4}$ production on a DM basis. The latter one may contribute to a lower VFA concentration if carbohydrate fermentation is reduced, and to an additional decrease in methanogenesis due to a specific action of tannins on methanogens (Martin et al. 2010). In the present study, these hypotheses were not confirmed. However, the very high $\mathrm{CP}$ content of forage diet in the rainy season showed a selective grazing for an increase in protein intake, as has been demonstrated in a similar ecosystem by Ayantunde et al. (1999). In our study, the 24-h incubation of forages, which is recommended for a global evaluation of the fermentation of low-quality forages, could have offset a synergy between low- and high-protein forage effects, which could occur only in the first hours after intake (Niderkorn et al. 2011). In three tropical tannin-rich forages, the absence of interaction among diet components on $\mathrm{CH}_{4}$ production has been shown by Rira et al. (2015). In Senegalese browse species, an interaction among diet components on digestibility has been found for some of them (Fall Touré et al. 1998) but the interaction among diet components on $\mathrm{CH}_{4}$ production is not known. In addition, the percentage of ligneous plants, which are mainly made of foliage and pods of shrubs and trees and have a low methanogenic potential (Soliva et al. 2008; Gemeda and Hassen 2015), was always lower than $10 \%$ in our study.

\section{Conclusions}

The present study has provided an overview of seasonal changes in potential $\mathrm{CH}_{4}$ emissions in forage diets grazed in arid tropics. It has also shown the importance of NDF as a determinant of methanogenic potential. However, several questions are raised. Can $\mathrm{CH}_{4}$ emissions be predicted only by chemical composition and digestibility of forages? Which kind of forages can limit $\mathrm{CH}_{4}$ emissions without impairing nutrient supply to animals? The in vitro approach can partially address these issues, in spite of limits in the interpretation of results. Nevertheless, a decisive step would be an in vivo experiment in which enteric $\mathrm{CH}_{4}$ emissions, intake and digestibility would be determined on grazing animals throughout the year.

\section{Acknowledgements}

The research leading to these results has been conducted as part of the AnimalChange project, which received funding from the European Community's Seventh Framework Program (FP7/ 2007-2013) under the grant agreement no. 266018. Authors are indebted to Dr Mohamadou Moustapha Cissokho, Fafa Sow and Abdou Diouf, and the staff in charge of animal care and management in Dahra-Djoloff ISRA research Centre, to Abdou Salam Sow, breeder in Niassanté, for care and management of his herd, to Laurent Bonnal (CIRAD, UMR Selmet, Montpellier, France) for NIRS analyses, to the staff in charge of donor animal care and feeding, especially Bernard Mallet(INRA, UERT, Saint-Genès Champanelle, France).

\section{References}

Adriansen HK, Nielsen TT (2005) The geography of pastoral mobility: a spatio-temporal analysis of GPS data from Sahelian Senegal. GeoJournal 64, 177-188. doi:10.1007/s10708-005-5646-y

Archimède H, Eugène M, Marie-Magdeleine C, Boval M, Martin C, Morgavi DP, Lecomte P, Doreau M (2011) Comparison of methane production between C3 and C4 grasses and legumes. Animal Feed Science and Technology 166-167, 59-64. doi:10.1016/j.anifeedsci.2011.04.003

Archimède H, Rira M, Eugène M, Morgavi DP, Anaïs C, Periacarpin F, Calif B, Martin C, Marie-Magdeleine C, Doreau M (2013) Intake, total-tract digestibility and methane emission of Texel and Blackbelly sheep fed C4 and $\mathrm{C} 3$ grasses tested simultaneously in a temperate and a tropical area. Advances in Animal Biosciences 4, 285.

Ayantunde AA, Hiernaux P, Fernandez-Rivera S, van Keulen H, Udo HMJ (1999) Selective grazing by cattle on spatially and seasonally heterogeneous rangeland in Sahel. Journal of Arid Environments 42, 261-279. doi:10.1006/jare.1999.0518

Baccouche A, Morgavi DP, Bois B, Genestoux L, Lecomte P, Ickowicz A, Diop T, Doreau M (2014) Methanogenic potential of tropical forages: 
in vitro evaluation and prediction from chemical composition. Proceedings of the Australian Society of Animal Production 30, 234.

Bodas R, Lopez S, Fernandez M, Garcia-Gonzalez R, Rodriguez AB, Wallace RJ, Gonzalez JS (2008) In vitro screening of the potential of numerous plant species as antimethanogenic feed additives for ruminants. Animal Feed Science and Technology 145, 245-258. doi:10.1016/j.anifeedsci. 2007.04.015

Chaokaur A, Nishida T, Phaowphaisal I, Sommart K (2015) Effects of feeding level on methane emissions and energy utilization of Brahman cattle in the tropics. Agriculture, Ecosystems \& Environment 199, 225-230. doi:10.1016/j.agee.2014.09.014

Chirat G, Groot JCJ, Messad S, Bocquier F, Ickowicz A (2014) Instantaneous intake rate of free-grazing cattle as affected by herbage characteristics in heterogeneous tropical agro-pastoral landscapes. Applied Animal Behaviour Science 157, 48-60. doi:10.1016/j.applanim.2014.06.003

Fall Touré S, Michalet-Doreau B, Traoré E, Friot D, Richard D (1998) Occurrence of digestive interactions in tree forage-based diets for sheep. Animal Feed Science and Technology 74, 63-78. doi:10.1016/ S0377-8401(98)00127-8

Gaidet N, Lecomte P (2013) Benefits of migration in a partially-migratory tropical ungulate. BMC Ecology 13, 36. doi:10.1186/1472-6785-13-36

Gemeda BS, Hassen A (2014) In vitro fermentation, digestibility and methane production of tropical perennial grass species. Crop and Pasture Science 65, 479-488. doi:10.1071/CP13450

Gemeda BS, Hassen A (2015) Effect of tannin and species variation on in vitro digestibility, gas, and methane production of tropical browse plants. Asian-Australasian Journal of Animal Sciences 28, 188-199. doi:10.5713/ajas.14.0325

Gerber P, Vellinga T, Opio C, Steinfeld H (2011) Productivity gains and greenhouse gas emissions intensity in dairy systems. Livestock Science 139, 100-108. doi:10.1016/j.livsci.2011.03.012

Gerber PJ, Steinfeld H, Henderson B, Mottet A, Opio C, Dijkman J, Falcucci A, Tempio G (2013) 'Tackling climate change through livestock: a global assessment of emissions and mitigation opportunities.' (FAO: Rome)

Guérin H, Friot D, Mbaye N, Richard D, Dieng A (1988) Régime alimentaire de ruminants domestiques (bovins, ovins, caprins) exploitant des parcours naturels sahéliens et soudano-saheliens. II. Essai de description du régime par l'étude du comportement alimentaire. Facteurs de variation des choix alimentaires et conséquences nutritionnelles. Revue d'Elevage et de Medecine Veterinaire des Pays Tropicaux 41, 427-440.

Intergovernmental Panel on Climate Change (IPCC) (2006) Emissions from livestock and manure management. In '2006 IPCC guidelines for national greenhouse gas inventories, vol. 4'. (Eds HS Eggleston, L Buendia, K Miwa, T Ngara, K Tanabe) pp. 10.1-10.87. (IGES: Kanagawa, Japan)

Kouazounde JB, Gbenou JD, Babatounde S, Srivastava N, Eggleston SH, Antwi C, Baah J, McAllister TA (2015) Development of methane emission factors for enteric fermentation in cattle from Benin using IPCC Tier 2 methodology. Animal 9, 526-533. doi:10.1017/S175173 1114002626

Lebel T, Diedhou A, Laurent H (2003) Seasonal cycle and interannual variability of the Sahelian rainfall at hydrological scales. Journal of Geophysical Research 108, 8389. doi:10.1029/2001JD001580
Macheboeuf D, Coudert L, Bergeault R, Lalière G, Niderkorn V (2014) Screening of plants from diversified natural grasslands for their potential to combine high digestibility, and low methane and ammonia production. Animal 8, 1797-1806. doi:10.1017/S1751731114001785

Martin C, Morgavi DP, Doreau M (2010) Methane mitigation in ruminants: from microbe to the farm scale. Animal 4, 351-365. doi:10.1017/ S1751731109990620

Meale SJ, Chaves AV, Baah J, McAllister TA (2012) Methane production of different forages in in vitro ruminal fermentation. Asian-Australasian Journal of Animal Sciences 25, 86-91. doi:10.5713/ajas.2011.11249

Morgavi DP, Martin C, Boudra H (2013) Fungal secondary metabolites from Monascus spp. reduce rumen methane production in vitro and in vivo. Journal of Animal Science 91, 848-860. doi:10.2527/jas.2012-5665

Niderkorn V, Baumont R (2009) Associative effects between forages on feed intake and digestion in ruminants. Animal 3, 951-960. doi:10.1017/ S1751731109004261

Niderkorn V, Baumont R, Le Morvan A, Macheboeuf D (2011) Occurrence of associative effects between grasses and legumes in binary mixtures on in vitro rumen fermentation characteristics. Journal of Animal Science 89, 1138-1145. doi:10.2527/jas.2010-2819

Ouédraogo-Koné S, Kaboré-Zoungrana CY, Ledin I (2008) Intake and digestibility in sheep and chemical composition during different seasons of some West African browse species. Tropical Animal Health and Production 40, 155-164. doi:10.1007/s11250-007-9075-4

Rira M, Morgavi DP, Archimède H, Marie-Magdeleine C, Popova M, Bousseboua H, Doreau M (2015) Potential of tannin-rich plants for modulating rumen microbes and ruminal fermentation in sheep. Journal of Animal Science 93, 334-347. doi:10.2527/jas.2014-7961

Rivière R (1991) 'Manuel d'alimentation des ruminants domestiques en milieu tropical.' (IEMVT, Ministère de la Coopération et du Développement, La Documentation Française: Paris)

Schlecht E, Blümmel M, Becker K (1999) The influence of the environment on feed intake of cattle in semi-arid Africa. In 'Regulation of feed intake'. (Eds D Van der Heide, EA Huisman, E Kanis, JWM Osse, MWA Verstegen) pp. 167-185. (CABI: London, UK)

Soliva CR, Zeleke AB, Clément C, Hess HD, Fievez V, Kreuzer M (2008) In vitro screening of various tropical foliages, seeds, fruits and medicinal plants for low methane and high ammonia generating potentials in the rumen. Animal Feed Science and Technology 147, 53-71. doi:10.1016/ j.anifeedsci.2007.09.009

Touré I, Ickowicz A, Wane A, Garba I, Gerber P (2012) 'Atlas of trends in pastoral systems in the Sahel. Information system on pastoralism in the Sahel.' (FAO and CIRAD: Rome, Paris)

Tran H, Salgado P, Tillard E, Dardenne P, Nguyen XT, Lecomte P (2010) 'Global' and 'local' predictions of dairy diet nutritional quality using near infrared reflectance spectroscopy. Journal of Dairy Science 93, 4961-4975. doi:10.3168/jds.2008-1893

Wallis de Vries MF (1995) Estimating forage intake and quality in grazing cattle: a reconsideration of the hand-plucking method. Journal of Range Management 48, 370-375. doi:10.2307/4002491 